\section{Phaeochromocytoma with ectopic calcitonin production and parathyroid cyst}

The triad of medullary carcinoma of the thyroid, phaeochromocytoma, and hyperparathyroidism is known as Sipples's syndrome. We report a case of unilateral phaeochromocytoma, hyperparathyroidism, and increased concentrations of serum calcitonin (CT) in which medullary carcinoma of the thyroid was not found.

\section{Case report}

A 55-year-old woman with moderate hypertension and a swelling in the front of the neck was admitted to the medical department. Her blood pressure fluctuated widely and she had tachycardia. Determinations of urinary catecholamine concentrations and angiography confirmed the presence of a unilateral phaeochromocytoma. Fluid from the fluctuating neck tumour contained $5 \mu \mathrm{g}$ parathyroid hormone (PTH) per litre, whereas the serum concentration was $2 \cdot 3 \mu \mathrm{g} / 1$ (normal range on radioimmunoassay ${ }^{1} 1 \cdot 1-2 \cdot 5$ $\mu \mathrm{g} / \mathrm{l})$. The serum calcium concentration was consistently raised, and the serum CT was $2 \cdot 8 \mu \mathrm{g} / 1$ (normal range on radioimmunoassay ${ }^{2} 0 \cdot 4-1 \cdot 0 \mu \mathrm{g} / 1$ ). Sipples's syndrome was suspected and she was transferred to the surgical department.

A right adrenal tumour was removed (operation 1). Postoperatively the urinary catecholamine concentrations decreased to normal or nearly normal, and serum calcium and CT became normal. Four weeks later the parathyroid cyst was extirpated and total thyroidectomy performed (operation 2). The PTH concentration in the cyst fluid was $10 \mu \mathrm{g} / \mathrm{l}$. Serum CT, serum calcium and urinary catecholamine concentrations were normal (see table).

Serum calcitonin and urinary catecholamine concentrations before and after operations

\begin{tabular}{|c|c|c|c|c|c|}
\hline & $\begin{array}{c}\text { Normal } \\
\text { values }\end{array}$ & $\begin{array}{c}\text { Before } \\
\text { operation }\end{array}$ & $\begin{array}{c}\text { After } \\
\text { operation } \\
1\end{array}$ & $\underset{2}{\text { After }} \underset{\text { operation }}{\underset{2}{2}}$ & $\begin{array}{c}\text { At } \\
\text { one-year } \\
\text { follow-up }\end{array}$ \\
\hline $\begin{array}{l}\text { Urinary adrenaline } \\
\text { (nmol/24 h). } \\
\text { Urinary noradrenaline }\end{array}$ & & $600 \cdot 6$ & $99 \cdot 4$ & 35.5 & 42.0 \\
\hline (nmol/24 h) & $59-473$ & $2659 \cdot 5$ & $208 \cdot 0$ & 126.5 & 104.0 \\
\hline $\begin{array}{l}\text { delic acid }(\mu \mathrm{mol} / 24 \mathrm{~h}) \\
\text { Serum calcitonin }(\mu \mathrm{g} / \mathrm{l})\end{array}$ & $\begin{array}{c}10-40 \\
0 \cdot 4-1 \cdot 0\end{array}$ & $\begin{array}{r}150 \cdot 7 \\
2 \cdot 8\end{array}$ & $\begin{array}{r}52.9 \\
0.6\end{array}$ & $\begin{array}{r}39 \cdot 3 \\
0.7\end{array}$ & $\begin{array}{r}19 \cdot 7 \\
0.7\end{array}$ \\
\hline
\end{tabular}

Conversion: SI to traditional units-Urinary adrenaline: $1 \mathrm{nmol} / 24 \mathrm{~h} \approx 0.183 \mu \mathrm{g} / 24 \mathrm{~h}$ Urinary noradrenaline: $1 \mathrm{nmol} / 24 \mathrm{~h} \approx 0 \cdot 169 \mu \mathrm{g} / 24 \mathrm{~h}$. Urinary vanillylmandelic acid: $1 \mu \mathrm{mol} / 24 \mathrm{~h} \approx 0 \cdot 2 \mathrm{mg} / 24 \mathrm{~h}$.

Histopathological and histochemical examination of the suprarenal tumour disclosed a typical phaeochromocytoma with characteristic chromaffinity Positive argentaffin and argyrophil reactions (Grimelius) occurred in the tumour cells. Masked metachromasia was shown (Solcia). CT was extracted from the tumour, ${ }^{3}$ the concentration being $15 \mathrm{ng} / \mathrm{g}$ wet tumour tissue; in a second assay the concentration was $15.5 \mathrm{ng} / \mathrm{g}$. Extensive examination of the cyst and entire thyroid including histochemical staining and immunofluorescence with anticalcitonin showed neither medullary carcinoma nor $C$ cells. Calcification and focal ossification were present but no amyloid was detected.

Repeated measurements over the next two years showed the urinary catecholamines, serum calcium, PTH, and serum CT to be within the normal ranges (table). A provocation test with calcium gluconate infusion increased the serum calcium to $3.9 \mathrm{mmol} / 1(15.6 \mathrm{mg} / 100 \mathrm{ml})$ but failed to increase the concentration of CT.

\section{Comment}

High concentrations of serum CT in medullary carcinoma of the thyroid is well documented. In our case neither medullary carcinoma nor C-cell characteristics were found in the thyroid, and the hormone was not detected by immunofluorescence. It is therefore unlikely that the CT was produced in the thyroid. The high serum concentrations of CT, which fell to normal after removal of the phaeochromocytoma, suggest that the phaeochromocytoma was the production site. Metastatic medullary carcinoma from an aberrant thyroid was excluded, and a calcium provocation test did not give evidence of other CT-producing metastases. The high concentration of CT in the phaeochromocytoma supports the hypothesis of local production there, as has previously been reported. ${ }^{4}$

The high serum calcium concentration was reduced to normal by adrenalectomy. Some workers have found a concomitant reduction to normal of PTH and suggested that the hypercalcaemia results from PTH released from the phaeochromocytoma or from the parathyroids as a consequence of adrenaline stimulation. ${ }^{5}$ Our patient did not have increased concentrations of circulating PTH. The concentration of PTH in the cyst fluid was, however, higher after removal of the phaeochromocytoma than before. Adrenaline stimulation of the hormone production was therefore unlikely. Nevertheless, possibly either CT or catecholamines stimulated the parathyroids at an earlier stage in the disease. A longlasting stimulus may have induced an adenomatous development with later cystic degeneration and autonomous hyperfunction of the parathyroids.

Requests for reprints should be addressed to: Dr Tore Kalager, Medical Department B, N-5016 Haukeland Sykehus, Norway.

1 Almquist, S, Hjern, B, and Wästed, B, Acta Endocrinologica, 1975, 78, 493. 2 Almquist, S, Telenius-Berg, M, and Wästed, B, Acta Medica Scandinavica, 1974, 196, 177.

${ }^{3}$ Hirsh, P F, Voelkel, E F, and Munson, P L, Science, 1964, 146, 412.

4 Voelkel, E F, et al, fournal of Clinical Endocrinology and Metabolism, 1973, 37, 297.

${ }^{5}$ Gray, R S, and Gillon, J, British Medical fournal, 1976, 1, 378.

(Accepted 11 March 1977)

University of Bergen, School of Medicine, Bergen, Norway

TORE KALAGER, MD, senior registrar, medical department $B$ ERNEST GLU'CK, MD, chief pathologist, Gade Institute (now deceased) PETER HEIMANN, MD, professor and head of surgical department OLE MYKING, MD, consultant in endocrinology

\section{Unusual presentations of pyrophosphate arthropathy}

We describe three patients with pyrophosphate arthropathy whose initial symptoms were misleading. One appeared to have acute septic arthritis, one presented with acute back pain, and one had symptoms resembling polymyalgia rheumatica. All symptoms were associated with joint effusions containing pyrophosphate crystals and all responded rapidly to anti-inflammatory drugs.

Early descriptions of pyrophosphate arthropathy emphasised its presentation as an episodic acute arthritis. It has now become clear that deposition of calcium pyrophosphate in joints may be associated with various clinical syndromes. ${ }^{1}$

\section{Case reports}

Case 1-A 57-year-old man was admitted to hospital with a two-week history of severe pain in the right ankle. He was feverish $\left(39.4^{\circ} \mathrm{C}\right)$, and continued to have a swinging fever with evening temperatures reaching $38.9^{\circ} \mathrm{C}$ for the first six weeks. There were gross deformities of both ankles, which were warm, swollen, and very tender on palpation and movement. Investigations showed: white cell count $15.9 \times 10^{9} / 1\left(15900 / \mathrm{mm}^{3}\right), 80 \%$ neutrophils; erythrocyte sedimentation rate (ESR) $130 \mathrm{~mm}$ in the first hour. Repeated cultures of blood and aspirate from the left ankle were sterile. $X$-ray examination of the ankles showed gross destructive changes with new bone formation; there were severe degenerative changes in both hips, and slight calcification of articular cartilage in the knees. Eleven days after admission the right ankle was explored. The synovial membrane contained large calcific deposits, and polarised light microscopy showed crystals of calcium pyrophosphate dihydrate. He was started on indomethacin, his temperature returned to normal, and for the first time since admission he could get out of bed.

Case 2-A 63-year-old man was admitted to hospital with a one-week history of low back pain. On the day of admission he had collapsed with pain while at work. He also complained of pains in his legs, shoulders, and hands. He had had intermittent backache for about ten years with attacks that he called "gout" in elbow, foot, and hand. Examination showed great limitation of movement of the lumbar spine with limited straight-leg raising. There were effusions in both knees and swelling of the ankles. He appeared to be in great pain. He had a slight fever $\left(37 \cdot 2^{\circ} \mathrm{C}\right)$. Investigations showed: white 
cell count $16.5 \times 10^{9} / 1\left(16500 / \mathrm{mm}^{3}\right), 90 \%$ neutrophils; ESR $131 \mathrm{~mm}$ in the first hour; serum uric acid $0.15 \mathrm{mmol} / 1(2.5 \mathrm{mg} / 100 \mathrm{ml})$. Aspiration of fluid from the knee confirmed the presence of crystals. $X$-ray pictures showed chondrocalcinosis of knees, shoulders, and hips. There were streaks of calcification in the annulus fibrosus ligament of the lumbar spine. He was given phenylbutazone and immediately improved. Subsequent investigations showed a raised serum iron concentration and liver biopsy confirmed the diagnosis of haemochromatosis.

Case 3-A 78-year-old man was admitted to hospital with a two-month history of pain in the neck and lower back accompanied by such severe stiffness that he could hardly move. Four years previously he had an episode of swelling of the left knee. All movements of the cervical and lumbar vertebrae were greatly limited and accompanied by severe pain. There was effusion in the left knee with warmth and tenderness. The white cell count was $8.0 \times 10^{9} / 1\left(8000 / \mathrm{mm}^{3}\right)$, and the ESR $42 \mathrm{~mm}$ in the first hour. Aspirate from the left knee showed calcium pyrophosphate crystals. $X$-ray examination of left knee showed chondrocalcinosis. He was treated with indomethacin improved remarkably, and was discharged after only one week in hospital.

\section{Comment}

These three cases illustrate some unusual clinical manifestations of pyrophosphate arthropathy. All patients presented with an acute illness of sudden onset, and all required admission to hospital. In the first case septic arthritis was simulated in a joint resembling a neuropathic joint. Destructive arthritis associated with pyrophosphate crystals had been described by Richards and Hamilton ${ }^{2}$. In the second case the acute onset of localised spinal pain suggested the possibility of acute disc prolapse. The cause of the spinal symptoms is uncertain, though there was calcification of the annulus fibrosus ligament similar to that described by Richards and Hamilton ${ }^{3}$. In the third case the association of stiffness and restriction of movement suggested the diagnosis of polymyalgia rheumatica.

We suggest that deposition of crystals in various sites caused these patients' symptoms, but it is difficult to prove. Radiological proof of chondrocalcinosis is not sufficient evidence for pyrophosphate arthropathy, since calcification may well be symptomless in older people. The association of symptoms with pyrophosphate deposition was suggested by their acute onset, inflammatory features such as raised ESR, the finding of effusions containing pyrophosphate crystals, and rapid response to non-steroidal anti-inflammatory drugs.

1 McCarty, D J, Bulletin on the Rheumatic Diseases, 1974, 25, 804.

2 Richards, A J, and Hamilton, E B D, Annals of Rheumatic Diseases, 1974, 33, 196.

${ }^{3}$ Richards, A J, and Hamilton, E B D, Rheumatology and Rehabilitation, 1976, 15, 138.

(Accepted 18 March 1977)

Hackney Hospital, London E9

G O STOREY, MD, FRCP, consultant rheumatologist

St Bartholomew's Hospital, London EC1A 7BE

E C HUSKISSON, MD, MRCP, consultant physician

\section{Profound hypothermia on combined lithium carbonate and diazepam treatment}

We report a case of profound hypothermia occurring on at least three occasions on combined lithium carbonate and diazepam treatment, but not occurring on either drug alone.

\section{Case report}

A 38-year-old woman with profound mental retardation since birth, but no evidence of genetic or metabolic defect, was treated with lithium carbonate to alleviate aggressive behaviour. The latter was added in August 1974 to a regimen of diazepam and perphenazine. Her first episode of hypothermia was reported in September 1974, when further phenothiazine treatment was discontinued. Occasional episodes of hypothermia continued to be reported, with lethargy and temperatures "below $35^{\circ} \mathrm{C}$." For six months from February 1975 she was maintained on diazepam alone with no reported hypothermia. Lithium was then begun again because of increasing aggression, and again hypothermia was reported. Because we felt that she needed these drugs, if possible, and because their role in causing hypothermia was doubtful we arranged two eight-week double-blind trials. Clothing was standardised and room temperature ranged $19-24^{\circ} \mathrm{C}$. In April 1976 , the first trial began of lithium carbonate $(1 \mathrm{~g}$ daily) alternating with placebo weekly. Diazepam ( $30 \mathrm{mg}$ daily) was given throughout. Rectal temperatures, room temperatures, and blood pressure were measured at 1000 and 2000 . No hypothermia was reported. The morning temperature on lithium was slightly lower than that on placebo $(P<0.05)$.

Rectal temperature with two drug regimens

\begin{tabular}{c|c|c}
\hline Time & Lithium + diazepam & Placebo + diazepam \\
\hline 1000 & $35.989 \pm 0.607$ & $36.333 \pm 0.410$ \\
2000 & $36.111 \pm 0.432$ & $36.350 \pm 0.357$ \\
\hline
\end{tabular}

After this trial, the patient continued on combined lithium and diazepam treatment and after 17 days of this she became profoundly hypothermic, her temperature falling from $35.4 \mathrm{C}$ to $32 \mathrm{C}$ over two hours. The patient was comatose, with reduced reflexes, dilated pupils, a systolic blood pressure between 40 and 60 , pulse rate of 40 , no piloerector response, and warm peripheries. All drug treatment was stopped and with warming, her temperature rose to $35.6^{\circ} \mathrm{C}$ over the next eight hours. A second trial of lithium carbonate ( $1 \mathrm{~g}$ daily) alone alternating with placebo was instituted. No significant temperature differences between lithium and placebo periods occurred. No hypothermic episodes occurred. Lithium carbonate ( $1 \mathrm{~g}$ daily) plus diazepam ( $20 \mathrm{mg}$ daily) were started again. Five days later, the patient became profoundly hypothermic: her temperature dropped from $35.5^{\circ} \mathrm{C}$ to $30^{\circ} \mathrm{C}$ in eight hours, and her physical state was similar to that noted on the first occasion. Again, her temperature rose to $32 \cdot 4^{\circ} \mathrm{C}$ over ten hours reaching $35^{\circ} \mathrm{C}$ within 24 hours.

Observations continued for a further six weeks on no drug treatment and no hypothermia was reported. Subsequently when she started on lithium carbonate ( $1 \mathrm{~g}$ daily) and diazepam ( $30 \mathrm{mg}$ daily) 36 hours later she became hypothermic, her rectal temperature falling from $35 \cdot 2{ }^{\circ} \mathrm{C}$ to $32.8{ }^{\circ} \mathrm{C}$ in four hours.

\section{Discussion}

Irvine ${ }^{1}$ reported the occurrence of hypothermia in an 84-year-old man given diazepam ( $10 \mathrm{mg}$ four times daily) for a week, who died. Mild hypothermia was seen at the other extreme of life-a temperature of $34.9^{\circ} \mathrm{C}$ and hypotonia being seen together with cyanosis in a newborn infant born to a mother taking lithium. ${ }^{2}$ Chlorpromazine is also associated with loss of temperature regulation due to lethargy and impairment of piloerection and vasoconstriction. ${ }^{3}$

Our patient did not develop hypothermia on lithium or diazepam alone, but exclusively on combined treatment. Throughout, she was active and aggressive, so that inactivity may be excluded as the cause. Normal serum thyroxine concentrations precluded thyroid malfunction, a known cause of hypothermia. ${ }^{4}$

The duration of treatment required to produce hypothermia appears to have progressively shortened in the patient. Since hypothermia is potentially fatal, we did not feel it was ethical to pursue this investigation further.

If this response is not idiosyncratic, then there may be potential danger to patients prescribed these drugs in combination.

We thank the nursing staff, ward 13, Strathmartine Hospital; Miss Miller, pharmacist, Royal Dundee Liff Hospital; and Mr J B Cooper, medical librarian, Ninewells Hospital and Medical School, for literature reseatch.

${ }^{1}$ Irvine, R E, British Medical fournal, 1966, 2, 1007.

2 Tunnesan, W W, et al, fournal of Pediatrics, 1972, 81, 804.

3 Hollister, L E, et al, Clinical Pharmacology and Therapeutics, 1960, 1, 284.

4 Jones, I H, and Moode, T W, Gerontologia Clinica, 1964, 6, 252.

(Accepted 11 March 1977)

Royal Dundee Liff Hospital, Dundee

G J NAYLOR, MD, BSC, consultant psychiatrist

A MCHARG, MB, CHB, registrar 